\title{
The Differences of Food Compositions in Adolescent Metabolic Syndrome in Malang
}

\author{
Sri Andarini ${ }^{1,2 *}$ and Djanggan Sargowo ${ }^{1 *}$
}

${ }^{1}$ Faculty of Medicine, University of Brawijaya, Malang

${ }^{2}$ Post Graduate Program in Biomedicine, University of Brawijaya, Malang

\section{Abstract}

B

ACKGROUND: Obesity, especially obesity in adolescent, is a worldwide health problem needing much of our attention because it can continue to be obesity in adulthood. About $50 \%$ obese adolescents grew up to be obese adults. It was a concern since it is one of risk factor associated with cardiovascular events including hypertension, dyslipidemia, insulin resistance and stroke. Visceral obesity is correlated with diabetogenic, atherogenic, prothrombotic, pro-inflammation, and abnormal metabolism. The objective of this study was to assess the prevalence of obese adolescents in Malang and to identitfy the differences in food compositions between metabolic syndrome and non-metabolic adolescents.

METHODS: Prevalence of obesity was determined by assessing BMI in 20 Senior and Junior High Schools. Metabolic syndrome was diagnosed using IDF criteria; waist circumference of $>80 \mathrm{~cm}$ and $>90 \mathrm{~cm}$ for female and male, respectively, and increased triglyceride and decreased HDL concentration levels. The food composition was assessed using food recalls, and then regression linier test was done to define the correlation between food intake and the components of metabolic syndrome.

RESULTS: The prevalence of adolescent obesity in Malang had reached $3.32 \%$, with the prevalence of obesity in male subjects higher than in female subjects, i.e. $54,1 \%$ compared to $45,9 \%$. The boys had higher mean for height and weight than the girls did, however, the BMI was higher in girls rather than boys. The difference of fat in food composition was significantly higher for the metabolic groups $(\mathrm{p}=0.031)$, but the carbohydrate did not significantly differ between the two groups $(\mathrm{p}=0.407)$.

CONCLUSIONS: The prevalence of adolescent obesity in Malang had reached $3.32 \%$, with the prevalence of $54.1 \%$ in male and $45.9 \%$ in female. From the statistics test, fat intake showed a significant difference between metabolic syndrome and non-metabolic syndrome groups, but other food compositions didn't.

KEYWORDS: Obesity, Metabolic Syndrome, Adolescent.

\section{Introduction}

Obesity is a new pandemic and is a preclinical indication of illness associated with life style. Obesity can enhance the development of cardiovascular disease from metabolic syndrome, thus it is now categorized as a cardiometabolic risk (CMR) factor. CMR factor includes nine components such as for classical components (smoking, high LDL level, hypertension, and increased glucose) and five risk factor (visceral obesity, low LDL level, insulin resistance, high TG level and inflammation) (1). In Indonesia, the prevalence of CMR can rapidly increase because Indonesian has the 
genetic traits of Asia but often follows Western style in eating food. Western people tend to eat food with high energy, sugar and saturated fat, but the physical activity tends to be minimal due to application of highly developed technology in daily life. Based on clinical experience in chronological evolution, illness associated with lifestyle can be classified as: Stage- 0 (healthy lifestyle), Stage-1 ("westernized", unhealthy lifestyle), Stage-2 (abdominal obesity), Stage-3 (metabolic syndrome, CMR, prediabetes, adolescent pre-diabetes), and Stage-4 (CMD, T2DM, stroke) (5).

Obesity can be diagnosed by several methods such as measurement of standard weight, height and weight table, body mass index, waist circumference, waist and hip ratio (WHR). skinfold caliper, or use of more advanced technology including computed tomography (CT), magnetic resonance imaging (MRI) and dual energy $\mathrm{X}$-ray absorption. Each method has both advantages and disadvantages. The main problem is in adjusting the standard with the population condition in the same method, e.g. measuring BMI to determine obesity in America and Europe population is different with in Asia, including Indonesia.

Metabolic syndrome is not an illness; it is a cluster of metabolic abnormalities such as visceral obesity, increased triglyceride and glucose concentration levels, decreased HDL and hypertension. This state can develop the cardiovascular disease including stroke by the progress of atherosclerosis (3). There are five recent definitions for metabolic syndrome such as obesity, dyslipidemia caused by increased triglyceride and decreased HDL, insulin resistance or glucose tolerance, and hypertension. The definition of metabolic syndrome was first defined by World Health Organization (WHO) with the criteria of having insulin resistance and two other criteria (4). The Europe group then developed the WHO definition by adding the measurement of plasma fasting glucose and established the minimum standard for waist circumference (94 $\mathrm{cm}$ and $80 \mathrm{~cm}$ for male and female, respectively) (5). The big change of definition was reported by NCEP ATP III who recommended the use of three out of five criteria to determine the metabolic syndrome. The difference of definition between WHO and NCEP ATP III is on glucose tolerance. Impaired glucose tolerance or insulin resistance became the main component in $\mathrm{WHO}$ definition while in NCEP ATP II definition, only the plasma fasting blood glucose is used instead of insulin resistance $(6,7)$.
Hence, this study was undergone in order to assess the prevalence of adolescent obesity in Malang and to identify the differences in food compositions between metabolic syndrome and non-metabolic syndrome adolescents.

\section{Methods}

Obesity prevalence was defined by measuring weight and height of students from 20 high schools in Malang (10 Junior High and 10 Senior High Schools) that were randomly chosen. To all the obese samples detected, examination was done to determine the metabolic status. Our former study found 3 adolescents with metabolic syndrome out of 11 obese adolescents. We examined 250 obese students, using IDF criteria by taking blood samples, from which we got 73 metabolic syndrome samples. For control samples, 77 students were taken using the criteria of sample group but adjusted with age, sex and the school. The data were analyzed using $t$ test to determine the result from each variable.

\section{Results}

Malang has 190 Junior and Senior High Schools (BPS, 2007). Out of the 190,20 schools were chosen which were 10 Junior High Schools and 10 Senior High Schools as shown in Table 1.

The study showed an adolescent prevalence of $3.32 \%$ with ratio of $54.1 \%: 45.9 \%$ for male and female, respectively. Out of 20 high schools SMP Negeri 5 had the highest prevalence $(5.03 \%)$ while SMA Negeri 5 had the lowest $(1.48 \%)$ prevalence.

Obese junior high school students were mostly from SMPN $3,4,5,6,12$, and 20 with the number of obese males higher than that of females.

Obese senior high school students were mostly from SMAN 2, 3, 7, 8, and 9 with the number of obese male higher than that of females.

From the mean of weight, height and BMI, it is concluded that the males has higher height and weight means than females, but the mean of BMI showed that females had higher scores than males. 
Table 1. The distribution of schools, the number of obese students adjusted to sex, examined students and the prevalence of obesity.

\begin{tabular}{|c|c|c|c|c|c|c|}
\hline & \multirow[t]{2}{*}{ Name of School } & \multicolumn{2}{|c|}{$\begin{array}{c}\text { The number of obesity } \\
\text { adjusted to sex }\end{array}$} & \multirow[t]{2}{*}{$\begin{array}{l}\text { Total obese } \\
\text { students }\end{array}$} & \multirow[t]{2}{*}{$\begin{array}{l}\text { Total examined } \\
\text { students }\end{array}$} & \multirow[t]{2}{*}{$\begin{array}{c}\text { Prevalence o } \\
\text { obesity }\end{array}$} \\
\hline & & M & $\mathbf{F}$ & & & \\
\hline 1 & SMP Negeri 1 & 5 & 7 & 12 & 564 & $2.13 \%$ \\
\hline 2 & SMP Negeri 3 & 10 & 5 & 15 & 534 & $2.81 \%$ \\
\hline 3 & SMP Negeri 4 & 11 & 7 & 18 & 509 & $3.54 \%$ \\
\hline 4 & SMP Negeri 5 & 28 & 13 & 41 & 815 & $5.03 \%$ \\
\hline 5 & SMP Negeri 6 & 11 & 6 & 17 & 461 & $3.69 \%$ \\
\hline 6 & SMP Negeri 8 & 8 & 10 & 18 & 579 & $3.11 \%$ \\
\hline 7 & SMP Negeri 10 & 9 & 9 & 18 & 407 & $4.42 \%$ \\
\hline 8 & SMP Negeri 12 & 6 & 3 & 9 & 546 & $1.65 \%$ \\
\hline 9 & SMP Negeri 20 & 5 & 11 & 16 & 592 & $2.70 \%$ \\
\hline 10 & SMP Negeri 21 & 17 & 11 & 28 & 801 & $3.50 \%$ \\
\hline 11 & SMA Negeri 1 & 6 & 13 & 19 & 512 & $3.71 \%$ \\
\hline 12 & SMA Negeri 2 & 15 & 12 & 27 & 674 & $4.01 \%$ \\
\hline 13 & SMA Negeri 3 & 15 & 9 & 24 & 601 & $3.99 \%$ \\
\hline 14 & SMA Negeri 4 & 3 & 10 & 13 & 573 & $2.27 \%$ \\
\hline 15 & SMA Negeri 5 & 7 & 8 & 15 & 483 & $3.11 \%$ \\
\hline 16 & SMA Negeri 6 & 11 & 18 & 29 & 720 & $4.03 \%$ \\
\hline 17 & SMA Negeri 7 & 13 & 5 & 18 & 464 & $3.88 \%$ \\
\hline 18 & SMA Negeri 8 & 15 & 12 & 27 & 655 & $4.12 \%$ \\
\hline 19 & SMA Negeri 9 & 7 & 1 & 8 & 455 & $1.76 \%$ \\
\hline \multirow[t]{2}{*}{20} & SMA Negeri 10 & 3 & 4 & 7 & 474 & $1.48 \%$ \\
\hline & TOTAL & $205(54,1 \%)$ & $174(45,9 \%)$ & 379 & 11.419 & $3.32 \%$ \\
\hline
\end{tabular}

Note: $\mathrm{M}=$ Male, $\mathrm{F}=$ Female

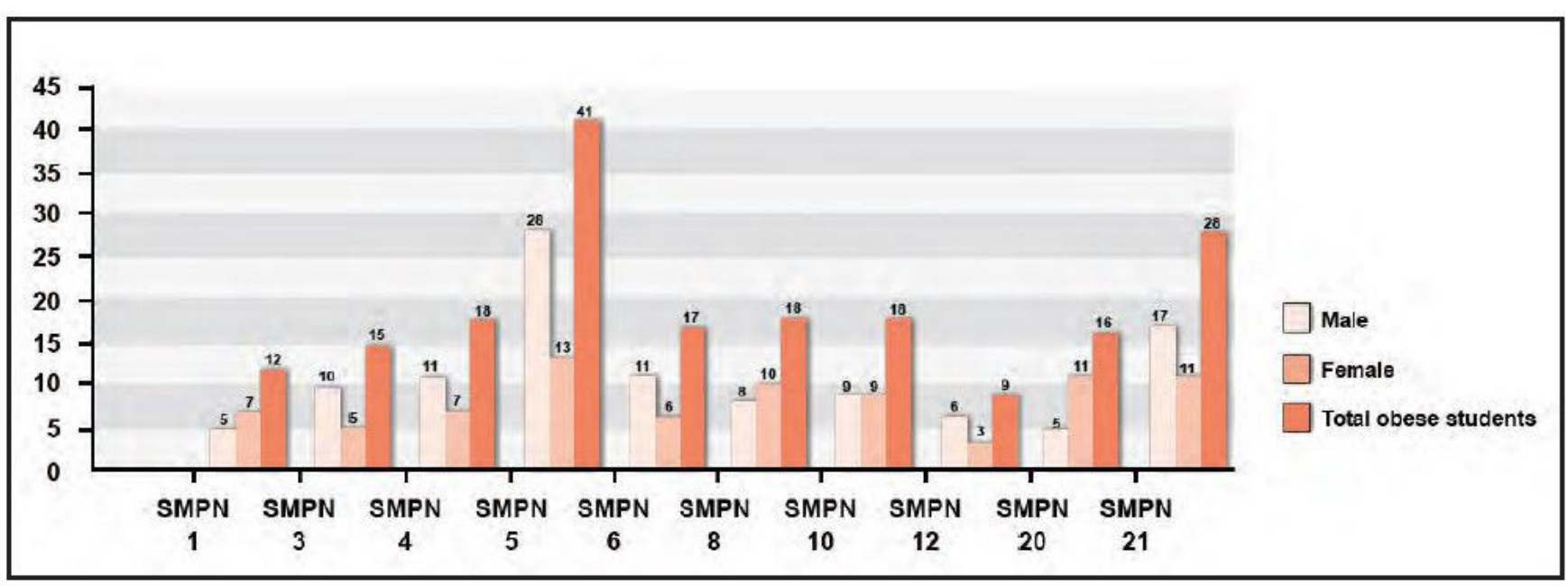

Figure 1. The number of obese junior high school students based on sex. 


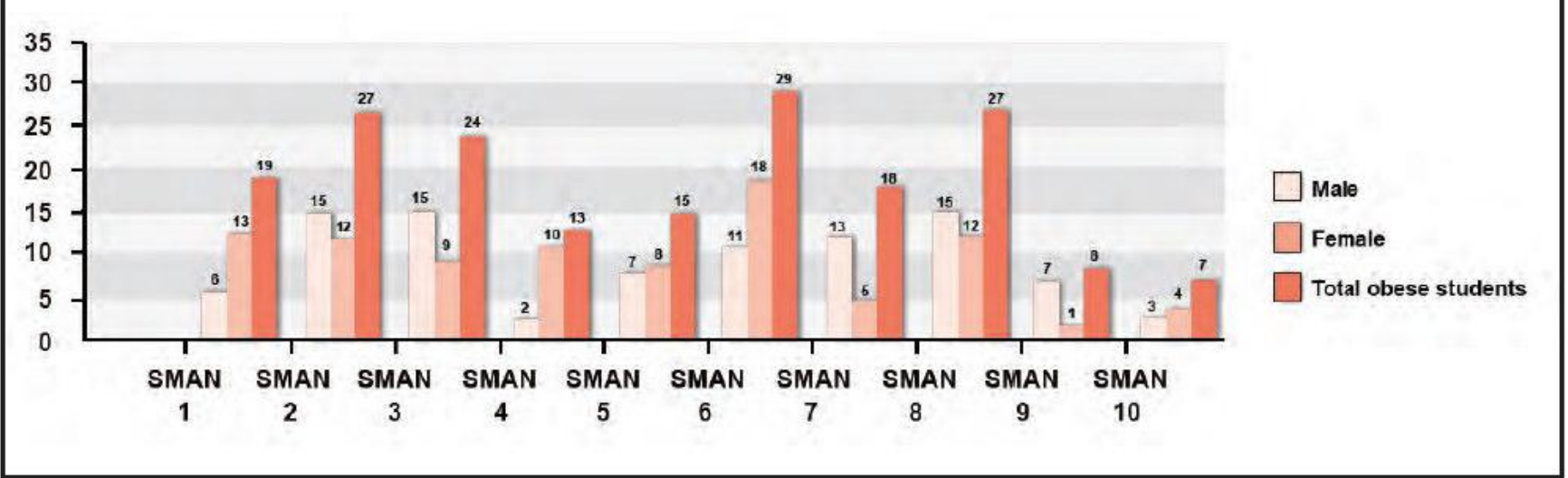

Figure 2. The number of obese senior high school students based on sex.

Table 2. The distribution of weight, height, and BMI means based on obese respondent's sex

\begin{tabular}{lccc}
\hline Sex & Weight $(\mathbf{k g})$ & Height $(\mathbf{c m})$ & Body Mass Index \\
\hline Male & 79.9138 & 161.7741 & 30.3818 \\
Female & 74.4823 & 156.5224 & 30.4027 \\
Total Mean Score & 77.4201 & 159.3631 & 30.3914 \\
\hline
\end{tabular}

Table 3. The distribution of metabolic and non-metabolic groups based on sex

\begin{tabular}{lcc}
\hline Sex & Metabolic Syndrome & Non-Metabolic Syndrome \\
\hline Male & $33(45,20 \%)$ & $28(36,36 \%)$ \\
Female & $40(54,80 \%)$ & $49(63,64 \%)$ \\
Total & $73(100 \%)$ & $77(100 \%)$ \\
\hline
\end{tabular}

THE CHARACTERISTICS OF METABOLIC SYNDROME AND NON-METABOLIC SYNDROME

The metabolic syndrome group was derived from obese respondents. Using IDF criteria with the modified waist circumference standard for Asian ( $>80 \mathrm{~cm}$ for female and $>90 \mathrm{~cm}$ for male), we have 73 metabolic syndrome samples and 77 non-metabolic samples.
Blood examination and waist circumference measurement showed the percentage of students with metabolic syndrome were $45.20 \%$ for male and $54.80 \%$ for female. On the other hand, the percentage of students without metabolic syndrome were $36.36 \%$ for male and $63.64 \%$ for female. The prevalence of metabolic syndrome could not be assessed here because not all students were willing to be punctured to get their blood. 


\section{THE DIFFERENCES BETWEEN METABOLIC}

SYNDROME AND NON-METABOLIC SYNDROME

The statistic assessment indicated a significant difference between metabolic syndrome and nonmetabolic syndrome subjects in the fat variable $(\mathrm{p}=0.031)$ while carbohydrate $(\mathrm{p}=0.407)$ and total calorie variables $(\mathrm{p}=0.104)$ showed no difference between two sample groups.

Table 4. The differences between metabolic and non-metabolic student based on test adjusted to weight, height, BMI, waist circumference, systole and diastole blood pressures, total cholesterol, triglyceride, LDL, HDL, fasting blood glucose, $2 \mathrm{~h}$ postprandial fasting blood glucose, adiponectin, apoB-100, and carbohydrate, fat and total calories intake.

\begin{tabular}{|c|c|c|c|}
\hline \multirow{2}{*}{ Variable } & MS (+) & MS (+) & \multirow{2}{*}{$\mathbf{P}$} \\
\hline & Mean \pm SD & Mean \pm SD & \\
\hline Weight (kg) & $81.5171 \pm 13.83657$ & $51.5075 \pm 7.53493$ & 0.000 \\
\hline Height $(\mathrm{cm})$ & $161.8795 \pm 8.40269$ & $158.1221 \pm 7.40108$ & 0.004 \\
\hline BMI (kg/m2) & $30.9185 \pm 3.05467$ & $20.6505 \pm 3.09737$ & 0.000 \\
\hline$W C(\mathrm{~cm})$ & $93.4603 \pm 6.21464$ & $69.6870 \pm 6.13751$ & 0.000 \\
\hline Systole $\mathrm{BP}(\mathrm{mmHg})$ & $122.5890 \pm 9.07811$ & $107.0390 \pm 7.52360$ & 0.000 \\
\hline Diastole BP ( $\mathrm{mmHg})$ & $85.2740 \pm 6.28584$ & $74.0260 \pm 7.52630$ & 0.000 \\
\hline Total cholesterol (mg/dl) & $198.5753 \pm 25.00551$ & $145.9221 \pm 14.20968$ & 0.000 \\
\hline Triglyceride (mg/dl) & $153.3699 \pm 19.35595$ & $114.2987 \pm 13.98690$ & 0.000 \\
\hline LDL (mg/dl) & $110.2466 \pm 22.59165$ & $55.4675 \pm 13.67536$ & 0.000 \\
\hline Fasting glucose (mg/dl) & $84.8219 \pm 6.44925$ & $83.3506 \pm 8.35272$ & 0.225 \\
\hline 2h Postprandial glucose (mg/dl) & $99.1096 \pm 7.16194$ & $97.0909 \pm 7.39599$ & 0.115 \\
\hline $\mathrm{HDL}(\mathrm{mg} / \mathrm{dl})$ & $59.0959 \pm 6.06255$ & $69.9091 \pm 5.42941$ & 0.000 \\
\hline Adiponectin (ng/dl) & $78.9145 \pm 20.83133$ & $117.8683 \pm 18.12649$ & 0.000 \\
\hline Apo B-100 (mg/dl) & $17.4242 \pm 15.66980$ & $11.9505 \pm 5.15948$ & 0.005 \\
\hline Carbohydrate & $51.4110 \pm 10.06070$ & $50.1818 \pm 7.96328$ & 0.407 \\
\hline Fat & $35.4932 \pm 9.27680$ & $32.1688 \pm 9.46100$ & 0.031 \\
\hline Total calorie & $1552.3027 \pm 595.64386$ & $1401.3935 \pm 503.42286$ & 0.104 \\
\hline
\end{tabular}

Systole BP = systole blood pressure, Diastole BP = diastole pressure, LDL= Low Density Lipoprotein, HDL= High Density Lipoprotein, Apo $\mathrm{B}-100=$ Apolipoprotein B-100, MS= metabolic syndrome. 


\section{Discussion}

Globally, developing and developed countries experience the increased prevalence of obesity among the adolescents. Not only Indonesia, but also Brazil experiences it, too. Data has suggested that the number of children and adolescent with obesity has increased three times from $1975-1997$. In Lebanon, 2104 adults and children age 3-19 shows that the prevalence and risk for obesity is higher for male than female ( $22.5 \%$ versus $16.1 \%$ for the risk and $7.5 \%$ versus $3.2 \%$ for the obese) (8).

Not only in developing countries, but also some developed countries also have the same problem, e.g. Australia and America. In Australia, the prevalence of obesity has doubled over the period of 1984-1994 and increased four fold in 1985-1997 (9). Among 2,272 Korean boys and girls' age 10-18 years old, the prevalence increased from $5.4 \%$ in 1998 to $11.3 \%$ in 2001 . In other words, the prevalence has doubled or increased as much as $5.9 \%$ in the period of 1998-2001 (10). In Canada, the prevalence of obese children age 7-13 also doubled from $5 \%$ to $14 \%$ for boys and $11 \%$ for girls in the period of 1981-1996 (11).

America is a country where the residents are multiracial. The increase of adolescent obesity is significant in America but the figures differ according to the ethnic group. For Caucasian youth, the prevalence has reach 11.3 in the period of 2003-2006 (12). This increase also applied to the African American where the figure has increased from $11 \%$ in $1988-1994$, to $15.5 \%$ in $1999-2000$ (13). The prevalence for Mexican American is even higher; it has reached $14.8 \%$ for boys and $13.7 \%$ for girls. It shows a 6\% national increase among obese adolescent from NHANES II data (14). From total 11.538 Native American age $5-17,47 \%$ boys and $41 \%$ girls are overweight; $24 \%$ among them are obese. The prevalence of overweight and obesity exceed the most recent data for American children in all age. In a 7-8 year survey, the prevalence of children with obesity is still increasing to $4.3 \%$. In Australia, the prevalence of overweight or obesity at the age of 13-14 in 1974-1984 did not show any change, but in 1984-1994, the prevalence of overweight increased $44-67 \%$ and the prevalence of obesity doubled in the same period.

Our results suggested that the prevalence of obesity in Malang has reached $3.32 \%$ of total adolescent population in senior and junior high school. It is not the same with the study conducted by Dewa (1998) which reported that the prevalence of obesity in Malang had reached $5.77 \%$. The population for the latter study, which was of private schools as the samples so the ethnic group studied was not purely Malayan may cause the difference. Riset Kesehatan Dasar (Riskesdas) in 2007 reported that the prevalence of obesity in people aged $>15$ years old is $10.3 \%$ (13.9\% for males and $23.8 \%$ for females). The study conducted by Riskesdas perhaps used the whole population in Indonesia while in fact there are many sub-ethnics that may determine the prevalence of obesity. However, there is a similarity between the two studies; the sex prevalence for male was higher than that for female. In our study, the prevalence was higher for boys $(54.1 \%)$ than for girls $(45.9 \%)$. It was also found in the Riskesdas study for children age 6-14 years old where the prevalence was $9.5 \%$ for boys and $6.4 \%$ for girls. The figure is similar to $\mathrm{WHO}$ which has estimated a prevalence of $10 \%$ for children aged 5-17 years old.

The criteria to diagnose metabolic syndrome varies between WHO, IDF, ASEAN and NCEP ATP III, which require three from five criteria to define metabolic syndrome $(15,16)$. Despite the ethnicity differences, the use of criteria is critical for assessing the prevalence of metabolic syndrome. For instance, the prevalence for African American is 39\% according to WHO, but the score become $27 \%$ if NCEP ATP III criteria is used (17). In this study, we used the criteria from IDF (International Diabetes Federation) and with that, we obtained 73 metabolic syndrome respondents. The prevalence was unaccountable in this study since not all of the students examined were willing to have their blood withdrawn. The prevalence of metabolic syndrome studied by Duncan suggested that the metabolic syndrome has reached 32.1 for adolescent with BMI in $>95^{\text {th }}$ percentile, while those with BMI in $85-95^{\text {th }}$ percentile had the prevalence of $7 \%$ (18). The prevalence of metabolic syndrome for Chinese Indonesian in North and South Jakarta is $19.14 \%$ for boys and $10.63 \%$ for girls (19). A Study on adults with metabolic syndrome was once done in Surabaya using ATP III criteria and found a prevalence of $32 \%$ (20).

In the state of metabolic syndrome, there is an increased in triglyceride concentration due to the increased atherogenic diet, decreased physical activity, and alcohol consumption. High calorie diet stimulates VLDL in the liver to increase the production of triglyceride, LDL, and decrease the HDL. In addition, saturated fat and cholesterol will activate LDL receptor that can enhance LDL and triglyceride (21). Hypertriglyceridemia is often associated with the decrease of HDL in obesity through the action of cholesteryl ester transfer protein (CETP) which facilitate the triglyceride transfer from triglyceride high lipoprotein (VLDL and chylomicron) toward HDL particles excessively.

The results suggested that the fasting blood glucose 
and $2 \mathrm{~h}$ postprandial blood glucose were still in the normal limit and the difference was insignificantly between both groups. This might happen because the insulin resistance which lead to impaired carbohydrate metabolism, has not occurred yet. Carbohydrate metabolism requires insulin as one of many hormones playing roles in maintaining the balance of glucose in the blood. This hormone works indirectly to the cells or organs, but it must be associated with a specific receptor in cell membrane or cell's cytosol. Metabolism abnormality will happen if there is a disturbance in a specific receptor or a change in the concentration level. The occurrence of type 2 diabetes mellitus is associated with three abnormalities namely (i) insulin resistance in peripheral tissue especially muscle, fat, and liver, (ii) impaired insulin secretion especially in response to glucose stimulation, and (iii) an increased production of glucose by liver (22). The fasting and $2 \mathrm{~h}$ postprandial blood glucoses were normal on both groups, and the results were insignificant in both metabolic syndrome and non-metabolic syndrome groups. It happened due to the impaired carbohydrate metabolism that has yet to occur in both groups.

$A p o B-100$ is a protein that can be found in VLDL, IDL (intermediate density lipoprotein), LDL, and ligand of LDL receptor (23). Among lipoproteins, apoB-100 plays an important role as the predictor of coronary cardiovascular disease; it is in fact more accurate in predicting the decrease of cholesterol in dyslipidemia treatment (24). The test and analysis of Apo B-100 suggested that no significant difference occurred between metabolic syndrome and nonmetabolic syndrome groups. This result does not match with Sattar's study in 2004. The study suggested that Apo B-100 was a better parameter than cholesterol next to $\mathrm{HDL}$ in indicating metabolic syndrome, which also related closely to central obesity, insulin resistance, thrombosis and inflammation (25). ApoB-100 is basically ampiphatic, meaning that it has hydrophobic and hydrophilic area to interact with the surrounding that consists of fat and water which plays an important role in lipoprotein metabolism. This apolipoprotein was suggested by NCEP to become an additional indicator in predicting patients with metabolic syndrome.

Adiponectin is a protein produced by adipocyte with molecular weigh of $30 \mathrm{kDa}$. Adiponectin is inducted during adipocyte differentiation and its secretion is stimulated by insulin. Adiponectin has two receptors, i.e. AdipoRl and $A d i p o R 2$ and it has been cloned. AdipoRl is produced in skeletal muscle, while AdipoR 2 can be found in liver tissue (26). The effect of adiponectin to carbohydrate metabolism is the increased sensitivity to insulin (27). It has been proven in animal models by injecting adiponectin that resulted in decreased glucose concentration (28). In a longer period, adiponectin can be used to treat hyperglycemia (29). Adiponectin improvement in the blood will decrease the risk of type 2 diabetes mellitus (30).

In this study, adiponectin concentration was quite low in the metabolic group compared to the non-metabolic group; the difference was significant. It is in accordance with Faraj's study in 2003 on the correlation between obesity and adiponectin concentration in the circulation, i.e. adiponectin would significantly increase along with the decrease in weight (31).

Concerning fat metabolism, adiponectin is thought to be able to decrease the entering free fatty acid into the liver and increase fatty acid oxidation contributing to the decrease in glucose output in the liver, triglyceride synthesis and VLDL. Adiponectin decreases fat synthesis and glucose production in the liver which results in the decrease of fatty acid and glucose levels in the blood. In addition, the production of triglyceride and fat oxidation are decreasing, causing raised energy release by muscles (32). The role of adiponectin is in fat oxidation, covering production and activity from protein associated with triglyceride metabolism including CD36, CoA oxidation acyl, 5-activated protein kinase PPAR $\gamma$ (33).

As anti-inflammation, adiponectin can inhibit TNF- $\alpha$ inducting the NF-kB actiovation by blocking IkB phosphorilation. In addition, adiponectin also inhibits the expression of scavenger receptor A-1 (SRA1) in macrophages so that the LDL oxidation is decreased and the forming of foam cell is inhibited (34). Adiponectin is also associated with immune system such as inhibits adhesion molecule expression of intracellular adhesion molecule-1 (ICAM-1), vascular cellular adhesion molecule-1 (VCAM-1) and E-selectin (35). In details, the role of adiponectin has been summarized by Tjokroprawiro, i.e increasing insulin sensitivity and decreasing glucose concentration by enhancing free fatty acid oxidation, reducing liver glucose production, decreasing intramyocellular fat contents and suppressing the NF-kB pathway. Adiponectin reduces insulin resistance by decreasing triglyceride in the muscle and liver. Adiponectin is stimulated by thyiazolidine (TZDs) through PPAR $\gamma$ and glimepiride, but inhibited by $-\alpha$, glucocorticoid, catecholamine. Adiponectin inhibits VCAM-1, ICAM-1 and E-selectin molecular adhesion, reduces TNF- $\alpha$ production, inhibits forming of fatty cells and preadipocyte differentiation, inhibits foam cells transformation from macrophages, inhibits heparin and EGF binding expression stimulated by TNF- $\alpha$. Low adiponectin level can be found in uncontrolled DM with cardiovascular disease and obesity. Female tends to have 
higher adiponectin level than male, so it lessen the risk of cardiovascular disease; high adiponectin level can also be observed in patients with uremia. Adiponectin becomes the treatment target for obesity, dyslipidemia, insulin resistance, metabolic syndrome and restenosis (20).

Food intake is one of determining factors of obesity occurrence that can also change to metabolic syndrome. Excessive food intakes that potentially develop obesity are fat and carbohydrate, since both will be stored in the fat cells if the quantity is more than appropriate. This condition will keep occurring if there is no balance in energy expenditure which also increase the risk of cardiovascular events. Study on German adolescents discovered the relationship between lifestyle aspects (fat diet, physical activity, aerobic and body fat) with cardiovascular disease risk factors (36).

The study resulted in a significant higher difference in fat intake between metabolic syndrome and non-metabolic syndrome groups, while carbohydrate intake did not differ significantly between both groups. This result was similar with Hill's (2000) study in proving that decreasing fat intake without calorie reducing diet would help in reducing weight (37). Bray and Popkin had also proved that lessening fat intake in the food without reducing calorie could reduce weight (38). It is still debated whether high fat diet can develop to obesity, but it is suggested that fat diet should be $<30 \%$ of the total energy. Low-fat diet is more effective in reducing LDL serum level, but low-carbohydrate diet works is more effective in decreasing LDL particles and also triglyceride serum level, postprandial lipemia, blood glucose, and weight (39). The insignificancy in carbohydrate intake between metabolic syndrome and non-metabolic syndrome groups might be due to the food composition in Indonesian adolescents diet which mostly consists of carbohydrate as the main food.

\section{Conclusions}

The prevalence of obesity for Malay adolescents in Malang is $3.32 \%$. Male adolescents has higher percentage compared to female with the ratio $54.1 \%: 45.9 \%$. From the statistics test, the fat intake was significantly higher in metabolic syndrome than the non-metabolic groups, while carbohydrate intake shows insignificantly between both groups.

\section{Acknowledgements:}

We would like to thank the Directorate General of Higher Education, Ministry of National Education, which has provided financial assistance so that this research can be done. Lastly, we offer my regards and blessings to all of those who supported us in any respect during the completion of the project.

\section{References:}

1. Tjokroprawiro A. The Trend in Emerging Lifestyle-related Diseases in Indonesia (From Obesity-MetS and CMR- to the CMDs). Kobe Association for the Study of Food And Health. Kasfah Memorial Meeting. Kobe, 5 July 2008.

2. Tjokroprawiro A. The High-Tech FDC of Metformn and Glibenclamide (Improving 2 Main Defects of T2DM and Showing 31 Cardiometabolic Properties). The XXIIIrd Continuing Medical Education (CME-XXIII) PKB-XXIII. Surabaya, 1-3 Agustus 2008.

3. Kahn R, Buse J, Ferrannini E, Stern M. The metabolic syndrome: time for critical appraisal: joint steatment from the American Diabetes Association and the Europian Association for the study of Diabetes. Diabetes Care 2005;28: 2289-2304.

4. Einhorn D, Reaven GM, Corbin RH. American College of Endocrinology, Position statement on the insulin resistance syndrome. Endocr Pract 2003;9: 237-252.

5. Balkau B, Charles MA. Comment on the provisional report from the WHO consultation. European group for the Study of Insulin Resistance (EGIR). Diabet Med 1999;16: 442443.

6. Miccoli R, Bianchi C, Prato SD. Pathophysiology of the metabolic syndrome. The Metabolic syndrome Full Guide, 2006; 9-14.

7. Tan CE, Ma S, Wai D, Chew SK, Tai ES. Can We Applay the national Cholerterol education Program Adult Treatment Panel Definition of the Metabolic Syndrome to Asian? Diab Care 2004; $27: 5$

8. Chakar H, Pascale R Salameh. Adolescent obesity in Lebanese private schools. Eur J Public Health 2006:16: 648-651.

9. Booth ML, Tien C, Melissa W, Kevin N, Kylie H, Jim D, and lan R. Change in the prevalence of overweight and obesity among young Australians, 1969-1997. Am J Clin Nutr 2003;77: 29-36.

10. Kim HM, Jong $\mathrm{P}$, Ho-Seong $\mathrm{K}$, Duk $\mathrm{H}$, and Sung Hoon $\mathrm{P}$. Obesity and Cardiovascular Risk Factors in Korean Children and Adolescents Aged 10-18 Years from the Korean National Health and Nutrition Examination Survey, 1998 and 2001. Am J Epidemiol 2006;164:787-793.

11. Hanley AJG, Stewart BH, Joel G, Thomas MS W, Brit S, and Bernard Z. Overweight among children and adolescents in a Native Canadian community: prevalence and associated factors1-3 Am J Clin Nutr 2000;71: 693-700.

12. Salvadori M, Jessica M. Sontrop, Amit XGa, Jennifer T, Rita SS. Elevated Blood Pressure in Relation to Overweight and Obesity Among Children in a Rural Canadian Community. Pediatrics 2008;122; e821-e827.

13. Cynthia L. Ogden CL, Margaret DC, Lester RC. Prevalence of Overweight and Obesity in the United States, 1999-2004. JAMA 2006;13:1549-1555. 
14. Lacar ES, MD, Xiomara S, William JR. Adolescent Obesity in a Low-Income Mexican American District in South Texas. Pediatr Adolesc Med 2000;154:837-840.

15. Miccoli R, Penno G, Bianchi C. Diagnostic criteria of metabolic syndrome. The Metabolic syndrome Full Guide 2006: 3-8.

16. Tan BK, Dennis H, Jing C, Farhatullah S, Raghu A, Stephen DK, Richard CK, Hendrik L, Harpal SR. Metformin Decrease the Adipokine Vaspin in Overweight Women With Polycystic Ovary Syndrome Concomitant With Improvement in Insulin Sensitivity and a Decrease in Insulin Resistance. Diabetes 2008;57 :1501-1507.

17. Ram Weiss, James Dziura., Tania S. Burget. Obesity and the Metabolic Syndrome in Children and Adolescents. N Eng J Med 2004;350:2362-74

18. Duncan GE, Li SM, Zhou XH. Prevalence and Trends of a Metabolic Syndrome Phenotype Among U.S. Adolescents 1999-2000. Diabetes Care 2004;27: 2438-2443.

19. Sibarani RP, Rudijanto A, Dekker J, Hiene RJ. The Petai China Study: Metabolic Syndrome Among Obese Indonesian Chinese Adolescents. Acta Med Indones 2006;38: 142144.

20. Tjokroprawiro A. The Metabolic Syndrome (LRD Stage-3): Preclinical Stage of the CVDs (LRD Stage 0-4, GULOHCISAR, Drug Intervention, "Time Bomb Disease") Simposium Sumpah Dokter FK UNS Periode-161. Holistic Approach of the Metabolic Syndrome. Surakarta, 9 September 2007.

21. Richard EB, Robert MK, Hal BJ. Defect in Metabolic of Lipids In: Nelson Textbook of Pediatrics. 17th ed. Philadelphia, Pennsylvania 2004: 448.

22. Buse JB, Kenneth S. Polonsky and Charles F. Burant. Type 2 Diabetes Mellitus. Williams Texbook of Endocrinology,2002:1427-1451.

23. Brunzell JD. Diagnosis and Treatment of Dyslpidemia. ACP Medicine. 2005

24. Kim JA, Montagnani M, Koh KK, Quon MJ. Reciprocal relationships between insulin resistance and endothelial dysfunction: molecular and pathophysiological mechaniSIMETs. Circulation 2006 113: 1888-1904.

25. Sattar N, Ken W, Allan DS, Ralph DA, Steven M. Comparison of the Associations of Apolipoprotein B and Non-HighDensity Lipoprotein Cholesterol With Other Cardiovascular Risk Factors in Patiens With the Metabolic Syndrome in the Insulin Resistance Atherosclerosis Study. Circulation 2004;110: 2687-2693.

26. Yamaguchi T, Kaamon J, Ito Y, Tsuchida A, Yokomizo T, Kita S Cloning of adiponectin receptor that mediate anti-diabetic metabolic effects. Nature 2003;432: 762-769
27. Bush NC, Darnell BE, Oster RA. Adiponectin is Lower African Americans and is Independently Related to Insulin Sensitivity in Children and Adolescents. Diabetes 2005;54: 2772-2778.

28. Berg AH, Combs TP, Du X, Brownlee M, Scherer PE. The adipocyte-secreted protein Acrp30 enhances hepatic insulin action. Nat Med. 2001;7:947-953.

29. Hoffstedt J, Poirier O, Thorne A. PolymorphisM of the human beta3-adrenoceptor gene forms a well-concerved haplotype that is associated with moderate obesity and altered receptor function. Diabetes 1999;48: 203-205.

30. Spanger L, Kroke A, Mohlig M, Wletek B, Harung HU. Adiponectin and protection against type 2 diabetes mellitus. Lancet 2003;361: 226-228.

31. Faraj M, Havel PJ, Phelis S, Blanck D, Snideman AD, Cianflone K. PlaSIMETa acylation-stimulating protein, adiponectine, leptin and ghrelin before and after weight loss induce by gastric bypass surgery in morbidly obese subjects. J Clin Endocrinol Metab 2003;88: 1594-1602.

32. Chandran M, Phillips SA, Ciaraldi T. Adiponectin: More Than Just Another Fat Cell Hormone?. Diab Care 2003;8: 2442 2450.

33. Tomas E, Tsao TS, Saha AK, Murrey HE, Zhang CC, Itani SL. Enchanced muscle fat oxidation and glucose transport by ACRP 30 globular domain: acetyl CoA carboxilase inhibition and AMP-activated protein kinase activation. Proc Natl Acad Sci USA 2002;99: 16309-16313

34. Matsuzawa Y, Funahashi T, Kihara S, Shimomura I. Adiponectin and Metabolic Syndrome. Arterioscler Thromb Vasc Biol 2004;24:29-33.

35. Matsushita K, Yatsuya H, Tamakoshi K, Wada K, Otsuka R, Takefuji S, Sugiura K, Kondo T, Murohara T, Toyoshima $\mathrm{H}$. Comparison of Circulating Adiponectin and Proinflammatory Markers Regarding Their Association With Metabolic Syndrome in Japanese Men. Arterioscler Thromb Vasc Biol 2006:26:871-877.

36. Bouziotas, Koutedakis, Nevill, Ageli. Greek adolescents, fitness, fatness, fat intake, activity, and coronary heart disease risk. Arch Dis Child 2004;89: 41-44.

37. Hill JO, Edward LMand Holly T W. Dietary Fat Intake and Regulation of Energy Balance: Implikasi for Obesity. J. Nutr 2000;130: 284S-288S.

38. Bray GA and Popkin BM. Dietary fat intake does affect obesity. Am J Clin Nutr 1998;68:1157-73

39. Sharman MJ. Very Low-Carbohydrate and Low-Fat Diets Affect Fasting Lipids and Postprandial Lipemia Differently in Overweight Men1 J. Nutr 2004.134: 880-885 